\title{
INSIDEN PENDERITA HIV/AIDS DENGAN KOMPLIKASI INTRAKRANIAL YANG DIRAWAT OLEH BAGIAN NEUROLOGI DI RSUP PROF. DR. R. D. KANDOU MANADO PERIODE JULI 2011 - JUNI 2012
}

${ }^{1}$ Sarlito Leunupun

${ }^{2}$ Mieke Kembuan

${ }^{2}$ Denny Ngantung

\author{
${ }^{1}$ Kandidat Skripsi Fakultas Kedokteran Universitas Sam Ratulangi Manado \\ ${ }^{2}$ Bagian Neurologi Fakultas Kedokteran Universitas Sam Ratulangi Manado \\ Email : brunnerleunupun@yahoo.co.id
}

\begin{abstract}
HIV (Human Immunodeficiency Virus) is a virus that causes immune deficiency that can lead to a collection of symptoms or the disease called AIDS (Acquired Immunodeficiency Syndrome) . Neurological complications occur in more than $40 \%$ of patients with HIV. Attack to the central nervous system is the most common and important manifestations of AIDS. In some patients, neurological manifestations may be the only picture that appeared or the earliest appearing in HIV infection. The purpose of this study is to describe the incidence of HIV patients with intracranial complications that treated by Neurology department in Prof. Dr. R. D. Kandou hospital period July 2011 - June 2012. A retrospective descriptive study. Research subject were all HIV patients with intracranial complication that hospitalized and treated by Neurology department in Prof. Dr. R. D. Kandou hospital from July 2011 to June 2012. Patients that include in inclusion criteria were all HIV patients with intracranial complication that treated by Neurology department in Prof Dr. R. D. Kandou Hospital.
\end{abstract}

Conclusion: From 31 patients, there were 13 patients (41,93\%) with intracranial complication. The most intracranial complication that found is cryptococcal meningitis.

Keywords: HIV, Intracranial complication, Opportunistic Infection

Abstrak: HIV (Human Immunodeficiency Virus) adalah suatu virus yang menyebabkan terjadinya penurunan kekebalan tubuh yang dapat menimbulkan kumpulan gejala atau penyakit yang disebut AIDS (Acquired Immunodeficiency Syndrome). Komplikasi neurologi timbul pada lebih dari $40 \%$ pasien dengan HIV. Serangan pada sistem saraf pusat merupakan manifestasi AIDS yang umum terjadi dan penting. Pada beberapa pasien, manifestasi neurologis dapat merupakan satu-satunya gambaran yang muncul atau yang paling awal muncul pada infeksi HIV. Tujuan penelitian ini adalah untuk mengetahui gambaran insiden penderita HIV dengan komplikasi intrakranial yang dirawat oleh bagian Neurologi di RSUP Prof Dr. R. D. Kandou Manado periode Juli 2011-Juni 2012.Penelitian deskriptif retrospektif. Subjek penelitian adalah Seluruh penderita HIV dengan komplikasi intrakranial yang pernah dirawat inap oleh bagian Neurologi di RSUP Prof. DR. R. D. Kandou Manado sejak Juli 2011 sampai Juni 2012. Pasien 
yang masuk dalam kriteria inklusi adalah semua penderita HIV dengan komplikasi intrakranial yang dirawat oleh bagian Neurologi di BLU RSUP Prof. DR. R. D. Kandou Manado.Kesimpulan: Dari 31 pasien yang menderita HIV, komplikasi intrakranial di temukan pada 13 pasien (41,93\%). Komplikasi Intrakranial yang paling banyak ditemukan adalah Cryprococcal Meningitis.

Kata Kunci: HIV, Komplikasi Intrakranial, Infeksi Oportunistik

\section{HIV (Human Immunodeficiency} Virus) adalah suatu virus yang menyebabkan terjadinya penurunan kekebalan tubuh yang dapat menimbulkan kumpulan gejala atau penyakit yang disebut AIDS (Acquired Immunodeficiency Syndrome). ${ }^{1}$

HIV/AIDS merupakan masalah besar yang mengancam Indonesia dan banyak negara di seluruh dunia. ${ }^{2}$ UNAIDS, badan WHO yang mengurusi masalah AIDS, memperkirakan jumlah orang yang terkena HIV/AIDS di seluruh dunia pada Desember 2004 adalah 35,9-44,3 juta orang, ${ }^{1}$ dan diperkirakan ada 22 juta orang yang meninggal dunia akibat AIDS sejak munculnya epidemik sampai tahun 2000 atau sekitar 20 tahun. ${ }^{3}$ Di Amerika Serikat, kasus pertama dilaporkan pada bulan Juni 1981. Sejak itu, 1,7 juta orang di AS diperkirakan telah terinfeksi HIV, termasuk lebih dari 619.000 orang yang telah meninggal dan sekitar 1,2 juta (1.178.350) orang dewasa dan remaja yang hidup dengan infeksi HIV pada akhir tahun 2008. ${ }^{4}$ Sedangkan di Cina, diperkirakan ada 780.000 orang yang hidup dengan HIV dan pada tahun 2011 sekitar 28.000 orang meninggal akibat AIDS. ${ }^{5}$ Epidemi AIDS di Indonesia diperkirakan masih akan berlangsung terus dan memberikan dampak yang tidak mudah diatasi. Menurut estimasi Nasional tahun 2006 di Indonesia terdapat 169.000 sampai 216.000 orang yang tertular HIV, dan akan menjadi satu juta orang dalam 10 tahun jika tidak melakukan upaya penanggulangan yang serius serta didukung oleh semua pihak. $^{6}$ Selanjutnya, dengan memperhatikan laporan kasus HIV/AIDS melalui data Dinas Kesehatan Provinsi Sulawesi Utara, menunjukkan bahwa sejak tahun 1997 sampai dengan bulan Juni tahun 2012, telah dilaporkan 1071 kasus HIV dan AIDS yang tersebar di 13 kabupaten/kota. ${ }^{7}$ Pada bulan Mei 2013, Sekretaris KPA Kota Manado dr Gherce Waru mengakui bahwa data kasus HIV 162 sedangkan AIDS 345, yang artinya menurut Waru sudah ada 507 kasus HIV/AIDS di Kota Manado yang sebelumnya tahun 2012 baru $496 .{ }^{8}$

Rasio kejadian AIDS pada pria dan wanita terus berubah tahun ketahun. Pada tahun 2009, rasio kejadian AIDS pada pria dan wanita adalah 4:1. Pada tahun 2010 rasio menjadi 3:1, dan pada tahun 2011 menjadi 2:1. ${ }^{2}$ Hasil penelitian yang ada menunjukkan bahwa angka kejadian AIDS banyak pada pria. ${ }^{9}$ Proporsi terbesar kasus HIV terdapat pada golongan umur 20-24 tahun, sedangkan proporsi AIDS terbesar terdapat pada golongan umur 25-29 tahun, yang mana merupakan golongan umur remaja dan dewasa muda. ${ }^{10}$

Komplikasi neurologi timbul pada lebih dari $40 \%$ pasien dengan HIV. ${ }^{11}$ Serangan pada sistem saraf pusat merupakan manifestasi AIDS yang umum terjadi dan penting. Sembilan puluh persen pasien menunjukkan adanya bentuk tertentu serangan neurologis pada saat autopsi, dan 40\% hingga 60\% mempunyai bukti klinis adanya disfungsi neurologis. Pada beberapa 
pasien, manifestasi neurologis dapat merupakan satu-satunya gambaran yang muncul atau yang paling awal muncul pada infeksi HIV. ${ }^{3}$

\section{METODE PENELITIAN}

Penelitian ini merupakan suatu penelitian yang bersifat deskriptif dengan metode retrospektif. Penelitian dilaksanakan di bagian Neurologi BLU RSUP Prof. DR. R. D. Kandou Manado dalam waktu kurang lebih dua bulan, yaitu dari Oktober 2013 sampai Desember 2013. Subjek Penelitian adalah seluruh penderita HIV dengan komplikasi intrakranial yang pernah dirawat inap oleh bagian Neurologi di RSUP Prof. DR. R. D. Kandou Manado sejak Juli 2011 sampai Juni 2012. Sampel Penelitian di ambil dengan memenuhi kriteria inklusi antara lain: Semua penderita HIV dengan komplikasi Intrakranial yang dirawat oleh bagian Neurologi di BLU RSUP Prof. DR. R. D. Kandou Manado. Variabel penelitian terdiri dari jumlah penderita, umur, jenis kelamin, pekerjaaan.

Penelitian dilakukan dengan cara mencari dan mengumpulkan bahan-bahan dari literatur, jurnal, internet yang berkaitan dengan materi yang diajukan sebagai judul. Mengambil data rekam medik penderita rawat inap dibagian Neurologi BLU RSUP Prof. DR. R. D. Kandou Manado pada tahun 2013. Pengolahan data dilakukan secara manual dengan mengelompokkan data berdasarkan variabel penelitian, kemudian menghitung dalam bentuk distribusi persentase. Menyajikan data dalam bentuk tulisan, dan tabel persentase.

\section{HASIL}

Berdasarkan data yang didapat dari Rekam Medik di BLU RSUP Prof. DR. Dr. R. D. Kandou Manado periode Juli 2011 Juni 2012, diperoleh data penderita HIV dengan komplikasi intrakranial yang dirawat oleh bagian Nerologi yaitu 13 orang. Semua penderita dimasukkan dalam penelitian ini karena memenuhi kriteria inklusi.

Berdasarkan data yang didapat menunjukan sebagian besar penderita HIV yang dirawat oleh bagian Neurologi adalah perempuan yaitu 7 orang atau sebesar $53,84 \%$ dari populasi yang ada, sedangkan penderita laki-laki sebanyak 6 orang atau $46,16 \%$ dari populasi.

Tabel 2. Distribusi Penderita HIV yang Dirawat oleh Bagian Neurologi Berdasarkan Jenis Kelamin

\begin{tabular}{ccc}
\hline $\begin{array}{c}\text { Jenis } \\
\text { Kelamin }\end{array}$ & $\begin{array}{c}\text { Jumlah } \\
\text { Orang }\end{array}$ & $\begin{array}{c}\text { Persentase } \\
\mathbf{( \% )}\end{array}$ \\
\hline Laki-Laki & 6 & 46,16 \\
Perempuan & 7 & 53,84 \\
\hline Jumlah & 13 & 100 \\
\hline
\end{tabular}

Berdasarkan data yang didapat, menunjukkan bahwa dari 13 penderita HIV yang dirawat oleh bagian Neurologi, umur terbanyak adalah antara 25-34 tahun sebanyak 6 orang atau sebesar 46,1\%, disusul kelompok umur 15-24 tahun sebanyak 4 orang atau 30,8\%, kelompok umur 45-54 tahun sebanyak 3 orang atau sebesar $23,1 \%$, dan untuk rasio umur yang lain tidak ditemukan.

Tabel 3. Distribusi penderita HIV yang dirawat oleh bagian Neurologi berdasarkan umur

\begin{tabular}{ccc}
\hline $\begin{array}{c}\text { Umur } \\
\text { (tahun) }\end{array}$ & $\begin{array}{c}\text { Jumlah } \\
\text { (orang) }\end{array}$ & $\begin{array}{c}\text { Persentase } \\
\text { (\%) }\end{array}$ \\
\hline $15-24$ & 4 & 30,8 \\
$25-34$ & 6 & 46,1 \\
$35-44$ & 0 & 0 \\
$45-54$ & 3 & 23,1 \\
$55-64$ & 0 & 0 \\
$65-74$ & 0 & 0 \\
$>75$ & 0 & 0 \\
\hline Jumlah & 13 & 100 \\
\hline
\end{tabular}


Berdasarkan data yang didapat, ditemukan pekerjaan yang paling banyak adalah tidak bekerja yaitu sebanyak 5 orang atau sebesar 38,5\%, disusul ibu rumah tangga yaitu sebanyak 4 orang atau 30,7\%, pegawai swasta sebanyak 3 orang atau $23,1 \%$, dan petani sebanyak 1 orang atau $7,7 \%$.

Tabel 4. Distribusi Penderita HIV dengan Komplikasi Intrakranial yang dirawat oleh Bagian Neurologi berdasarkan pekerjaan

\begin{tabular}{ccc}
\hline Pekerjaan & $\begin{array}{c}\text { Jumlah } \\
\text { (orang) }\end{array}$ & $\begin{array}{c}\text { Persentase } \\
\text { (\%) }\end{array}$ \\
\hline Ibu Rumah & 4 & 30,7 \\
Tangga & & \\
Petani & 1 & 7,7 \\
Pegawai & 3 & 23,1 \\
swasta & & \\
Tidak & 5 & 38,5 \\
Bekerja & & \\
\hline Jumlah & 13 & 100 \\
\hline
\end{tabular}

Berdasarkan data yang didapat, ditemukan jumlah penderita HIV dengan komplikasi intrakranial yang dirawat oleh bagian Neurologi adalah 11 pasien, dengan keterangan sebagai berikut : Ensefalitis Toxoplasma 2 orang atau 18,1\%, Cryptococcal Meningitis 3 orang atau 27,3\%, limfoma sistem saraf pusat dan leukoensefalopati multifocal progresif tidak ada, ensefalitis toxoplasma + cryptococcal meningitis 3 orang atau 27,3\%, dan komplikasi intrakranial lainnya (stoke, CMV) 3 orang atau 27,3\%.

Tabel 5. Distribusi Penderita HIV dengan Komplikasi Intrakaranial Yang Dirawat Oleh Bagian Neurologi berdasarkan komplikasi

\begin{tabular}{ccc}
\hline Komplikasi & Jumlah & $\begin{array}{c}\text { Persentase } \\
\text { Intrakranial }\end{array}$ \\
\hline
\end{tabular}

\begin{tabular}{|c|c|c|}
\hline Ensefalitis & 2 & 15,4 \\
\hline $\begin{array}{c}\text { Cryptococcal } \\
\text { Meningitis }\end{array}$ & 3 & 23,1 \\
\hline $\begin{array}{c}\text { Limfoma Sistim } \\
\text { Saraf Pusat }\end{array}$ & 0 & 0 \\
\hline $\begin{array}{c}\text { Leukoensefalop } \\
\text { ati Multifokal } \\
\text { progresif }\end{array}$ & 0 & 0 \\
\hline Ensefalitis & 3 & 23,1 \\
\hline $\begin{array}{l}\text { Toxoplasma + } \\
\text { Cryptococcal } \\
\text { Meningitis }\end{array}$ & & \\
\hline Lainnya & 3 & 38,4 \\
\hline Jumlah & 13 & 100 \\
\hline
\end{tabular}

\section{BAHASAN}

Sesuai hasil penelitian secara retrospektif di Bagian Rekam Medik BLU RSUP Prof. DR. Dr. R. D. Kandou Manado yang diambil dari Irina B, Irina C5, Irina F Isolasi dan Irina Anggrek dalam periode Juli 2011 - Juni 2012 didapati 31 orang yang menderita HIV dengan jumlah pasien yang mengalami komplikasi intrakranial yang dirawat oleh bagian Neurologi adalah 13 orang.

Penderita HIV dengan komplikasi intrakranial yang didata sangat sedikit. Hal ini disebabkan adanya sebagian berkas pasien HIV di bagian rekam medik tidak ditemukan, baik karena tercecer maupun hilang.

Pada penderita yang terdata dan memenuhi kriteria inklusi, didapatkan bahwa penderita HIV dengan komplikasi intrakranial yang di rawat inap oleh bagian Neurologi lebih banyak perempuan dengan persentase 53,84\%, dibandingkan dengan penderita laki-laki (tabel 2). Hal ini dapat diakibatkan oleh semakin banyaknya wanita yang bekerja sebagai pekerja seks komersial. Jumlah PSK yang terdata pada tahun 2010 berjumlah 498 orang, ${ }^{29}$ dan pada tahun 2011 
meningkat 64\% menjadi 812 orang. ${ }^{30}$ Data tersebut sesuai dengan referensi yang memaparkan perbandingan antara penderita HIV pada laki-laki dan perempuan mengalami perubahan dari tahun ke tahun, rasio penderita laki-laki dan perempuan yaitu 4:1 pada 2009, 3:1 pada 2010, dan 2:1 pada $2011{ }^{2}$

Selain pada perempuan, presentase penderita HIV dengan komplikasi intrakranial yang di rawat oleh bagian Neurologi terbanyak yang digolongkan menurut umur menunjukan bahwa, penderita terbanyak pada kelompok umur 25 - 34 tahun yang mencapai 46,1\%.(tabel 3). Fakta ini dapat di pahami karena pada kelompok tersebut merupakan kelompok dewasa muda dimana kelompok ini memiliki perilaku seksual aktif, yang merupakan faktor resiko penyakit HIV. ${ }^{10}$

Berdasarkan jenis pekerjaan, dari 13 pasien yang paling banyak menderita HIV dengan komplikasi intrakranial yang dirawat oleh bagian Neurologi adalah pasien yang tidak bekerja yaitu mencapai 38,5\%.(tabel 4). Hal ini berhubungan erat dengan tingkat pengetahuan yang ada pada masyarakat yang masih sangat kurang, terutama pada mereka dengan tingkat pendidikan rendah, atau mereka yang tidak bekerja. Kemudian menyusul ibu rumah tangga sebesar 30,7\% dari 13 pasien. Ini sesuai dengan kepustakaan yang mengatakan bahwa sejak 2007, ibu-ibu rumah tangga adalah kalangan yang paling rentan tertular HIV/AIDS melalui hubungan seks dengan suaminya. Hal ini dapat diakibatkan oleh budaya patriarki (posisi wanita di bawah pria) yang kuat di negara-negara Asia yang mengakibatkan tidak dapat didiskusikannya masalah seks kepada pasangannya. ${ }^{11}$

Berdasarkan komplikasi intrakranial, dari data yang didapat komplikasi intrakranial yang paling banyak adalah Cryptococcal Meningitis, yaitu sebesar 23,1\% (tabel 5). Data ini sesuai dengan penelitian yang dilakukan oleh Zelalem Temesgen dari Mayo clinic di Kenya pada tahun 2012 yang menyatakan komplikasi intrakranial yang paling banyak diderita oleh penderita HIV di rumah sakit Nairobi adalah Cryptococcal Meningitis, yaitu sebanyak 22\%. ${ }^{12}$ Hasil ini berbeda dengan hasil yang ditemukan di Amerika. Data pada Brazilian Journal of Infectious Diseases tahun 2012 menunjukan, komplikasi intrakranial paling banyak diderita adalah ensefalitis toxoplasma, yaitu $10-40 \% .^{13}$ Kemungkinan besar tingginya insiden Cryptococcal di Afrika dan Asia mencerminkan perbedaan dalam pemaparan daripada kelemahan host atau cryptococcal strain virulensi, meskipun belun ada penelitian yang membahas tentang masalah ini. ${ }^{14}$

\section{SIMPULAN DAN SARAN}

Penderita HIV dengan komplikasi intrakranial terbanyak adalah perempuan. Penderita HIV dengan komplikasi intrakranial terbanyak pada kelompok umur 25 - 34 tahun. Penderita HIV dengan komplikasi intrakranial terbanyak adalah tidak punya pekerjaan. Kompikasi intrakranial yang paling banyak ditemukan pada penderita HIV adalah Cryptococcal Meningitis.

Melihat angka kejadian HIV yang terus meningkat dari tahun ke tahun, dapat dilihat adanya masalah serius. Hal ini memerlukan penanganan yang lebih baik dan holistik untuk mencegah semakin meningkatnya angka kejadian HIV/AIDS. Mengingat juga komplikasi yang disebabkan oleh HIV sangat serius dalam dunia kedokteran,

Sebagai wujud pengabdian pada masyarakat, seluruh bagian perlu mensosialisasikan pada masyarakat tentang bahayanya HIV. Maksudnya disini tentang apa itu HIV, bahayanya HIV dan cara penularannya agar masyarakat dapat 
menghindari resiko terjadinya penularan HIV.

Sampel yang didapatkan dalam penelitian ini sangat sedikit akibat kurang maksimalnya proses penyimpanan dan

\section{DAFTAR PUSTAKA}

1. Djoerban Z, Djauzi S. HIV/AIDS di Indonesia. Dalam : Sudoyo AW, Setiyohadi B, Alwi I, Simadibrata M, Setiati S. Buku Ajar Ilmu Penyakit Dalam jilid III edisi V. Interna Publishing; Jakarta 2009 : 2861-70

2. Muhaimin T. Impact of HIV/AIDS in the family on children's quality of life. Med J Indonesia 19:280-6, 2010

3. Mitchell RN, Kumar V. Penyakit imunitas. Dalam : Kumar V, Cotran RS, Robbins SL. Buku Ajar Patologi volume I edisi VII. Penerbit Buku Kedokteran EGC; Jakarta 2007 : 113-84

4. U.S. Statistics [internet] 2012 Jan 1 [updated 2012 Jul 6; dikutip 2013 oct 26]. Available from: http://aids.gov/hiv-aids-basics/hivaids-101/statistics/

5. HIV \& AIDS in China. From: http://www.avert.org/hiv-aidschina.htm

6. Komisi penanggulangan AIDS. Stop AIDS. Jakarta 2006

7. Laporan Kuartal Kesembilan (Q9) SR KPA Provinsi Sulawesi Utara Periode Juli - September 2012

8. HIV/AIDS di Manado tercatat 507 kasus. Tribun News 2013 Augut 21:11

9. Satyabakti P. Epidemiology of HIV AIDS in Indonesia. Department of epidemiology affairs, tropical and infectious disease Airlangga University Hospital. Jakarta 2012

10. Suryoputro A, Ford NJ, Shaluhiyah Z. Faktor-faktor yang mempengaruhi pengelolaan rekam medis di RSUP Prof. DR. Dr. R. D. Kandou, sehingga disarankan untuk diadakan pengelolaan yang lebih baik contohnya lewat penyimpanan menggunakan sistem komputerisasi.

perilaku seksual remaja di Jawa Tengah: implikasinya terhadap kebijakan dan layanan kesehatan seksual dan reproduksi. Makara, Kesehatan 10:29-40, 2006

11. Wanita Rentan Tertular HIV/AIDS. Arsip Harian Sumut Pos [Internet]. 2010 Agustus 22. [mengutip 2014 Januari 14]; Available from: http://www.hariansumutpos.com/arsi $\mathrm{p} / \mathrm{p}=59374$

12. Temesgen $Z$. Neurological Complication of HIV. Division of Infectious Diseases Mayo Clinic. Kenya 2012.

13. Gomes MM. Neurologic complications of HIV in the HAART era. Braz J Infect Dis 16:373-8, 2012

14. Bianic T. Harrison TS. Cryptococcal Meningtis. British Medical Bulletin. 2005 Feb-Aprl;72:99-118 